\title{
The Transformation of Regional Government Policies in Maintaining Economic and Health Stability in the New Normal Era
}

\author{
Yulia Rimapradesi ${ }^{1 *}$, Siti Fajrina ${ }^{2}$ \\ 1,2Master of International Relations, Faculty of Social and Political Sciences, Universitas \\ Muhammadiyah Yogyakarta, Jl. Brawijaya, Kasihan, Bantul, 55183, Indonesia
}

Received: 2021-09-10; Accepted: 2021-10-28; Published: 2021-10-31

\begin{abstract}
It has been more than one year that the Covid-19 pandemic has hit Indonesia. In the face of this pandemic, governments from the national and district levels have responded with policies that limit social activities, resulting in decreased mobility in the community to prevent the transmission of Covid-19. This ultimately has an impact on economic growth. In addition, policies in the health sector are also the main thing, starting from the handling of Covid19 patients at the beginning of the pandemic to the provision of vaccines in the New Normal era. The focus of this writing will look at the transformation of local government policies in the New Normal era of two districts in Indonesia, namely South Bengkulu (Bengkulu) and Pidie (Aceh) to maintain economic stability and health in their regions. By using a policy implementation approach and qualitative descriptive analysis methods, this article aims to understand how local government policies transform in the pandemic era. This study concludes that the policy transformation of the local government of Bengkulu Selatan and Pidie districts in maintaining economic stability and the district generally follows the rules from the central government, but is adjusted to the situation and conditions of the district, such as the Covid-19 transmission rate and the budget owned by each region respectively.
\end{abstract}

Keywords: Regional Government Policies; Covid-19; Bengkulu; Aceh

How to Cite: Rimapradesi, Y., \& Fajrina, S. (2021). The Transformation of Regional Government Policies in Maintaining Economic and Health Stability in the New Normal Era. Journal of Contemporary Governance and Public Policy, 2(2), 134-144. https://doi.org/10.46507/jcgpp.v2i2.46.

Permalink/DOI: https://doi.org/10.46507/jcgpp.v2i2.46 


\section{Introduction}

The emergence of the Corona Virus Disease 2019 (Covid-19) has attracted the attention of the global community. The World Health Organization has declared that Covid19 is a public health emergency. The speed with which countries are taking action to respond to this pandemic also varies with some governments taking action after the first cases are confirmed (McKenzie \& Adams, 2020). Indonesia is the fourth most populous country in the world and the Indonesian Government's response to the Covid-19 crisis has been very slow. Unresponsive and wrong policies certainly endanger millions of Indonesian people (Agustino, 2020). The number of infected cases has soared, from the first cases announced on March 2, 2020 , to 1,500 cases at the end of March, and further jumped to 6,575 cases on April 20, 2020 and on April 16,2021 , reaching $1,594,722$ positive cases (Purnamasari, 2021).

The effects and infections of the Covid-19 virus pandemic affect almost all regions of Indonesia. The Government is working as quickly as possible to provide policies that can reduce the effects and infections of the Covid-19 virus. South Bengkulu and Pidie districts are two districts on the island of Sumatra. The spread of the Covid-19 virus in the South Bengkulu district can still be relatively low compared to other districts on Java. This is due to several factors, where the population in South Bengkulu is only 153,930 thousand according to data from the statistical agency in 2016 (Badan Pusat Statistik Kabupaten Bengkulu Selatan, 2018). According to data from the Covid-19 task force in the South Bengkulu district, on April 1, 2021, 176 people tested positive for COVID-19 as evidenced by RT-PCR laboratory tests, and 17 people died positively of Covid-19. (Covid19 Kabupaten Bengkulu Selatan, 2021).

This figure is relatively small, considering that Covid-19 has entered Indonesia for more than one year. The mobility of the people who mostly do not use public transportation and are not in industrial areas or student cities makes South Bengkulu still relatively low in the mobility of immigrants so that in general, the Covid-19 cases in South Bengkulu can still be monitored with the majority of cases of the infection being people who just travelled or came back from out of town (Usmin, 2020).

In contrast, Pidie District has been assigned a red zone due to the pandemic, although so far, there has been a decrease in positive cases of Covid 19 and again declared a green area. Covid 19 data in Pidie as of April 2021 confirmed 489 points, and 52 people died (LPP Aceh, 2020). The pandemic has had a significant impact on the economy in Pidie. The determination of WFH (Work From Home) and the limitation of working hours have decreased the performance of offices and business fields so that it affects the policies of real sector actors, namely laying off employees and layoffs (Termination of Employment). The appeal to reduce outdoor activities, maintain distance (physical distancing), and the WFH policy, has resulted in decreased performance activities in various sectors so that these problems reduce people's income and weaken purchasing power (LPP Aceh, 2021).

From data from the Central Bengkulu Regency Statistics Agency, Bengkulu Province also recorded a slowdown in the economic growth of $0.02 \%$ in 2020 and specifically, South Bengkulu Regency experienced a slowdown of $0.26 \%$. This figure is the highest figure of the economic growth 
rate of other districts in Bengkulu, but this figure is far from the economic growth in 2019, which reached $4.47 \%$. (Badan Pusat Statistik Kabupaten Bengkulu Selatan, 2021).

The effects of the Covid-19 pandemic are indeed not easy to deal with, but the government is required to be ready at all times to renew and transform policies in the face of a dynamic pandemic situation. With various policies in handling Covid-19, the Government is trying to prevent the spread of the virus. Anderson said, public policy is a path of action deliberately taken by an actor or a number of actors in solving a problem or a number of focus problems (Luth \&Meriwijaya, 2021). Therefore, the world will not be able to remain silent forever in the face of economic recession and the decline in health workers, there must be a solution to lead a new life. Central government policy is a reference for local governments to establish a policy so that it is right on target at the conditions of the community in the area. This is due to different factors and field conditions. Thus, this paper will describe how the policy transformation of the local government of Bengkulu Selatan Regency, Bengkulu and Pidie Regency, Aceh in maintaining economic stability and health in the New Normal era.

\section{Research Methods}

In this study, the author used qualitative approach with descriptive analysis method. The authors describes the policy transformation in Bengkulu Selatan Regency and Pidie Regency in handling Covid-19. Where this paper will later aim to provide information related to how Covid-19 has a role in economic influence in the region.

The source of this research data are collecting data through research literature observations taken from local government news and information. The data presented in this study comes from secondary data sourced from books, scientific journals, news and various government agencies/services which are then elaborated and presented together with the latest analysis of events that occurred.

\section{Results and Discussion}

\section{Initial Policy of South Bengkulu Regency Government Before New Normal}

The spread of the Covid-19 virus in Bengkulu Selatan district can still be relatively low compared to other communities on the island of Java. This is due to several factors, the population in South Bengkulu is only 153,930 thousand, according to statistical data in 2016 (Badan Pusat Statistik Kabupaten Bengkulu Selatan, 2018). According to data from the Covid-19 task force in the South Bengkulu district, on April 1, 2021, 176 people tested positive for COVID19 as evidenced by RT-PCR laboratory tests, and 17 people died a positive state of Covid-19. (Covid19 Kabupaten Bengkulu Selatan, 2021).

This figure is relatively small, considering that Covid-19 has entered Indonesia for more than one year. The mobility of the people who mostly do not use public transportation and are not in industrial areas or student cities makes South Bengkulu still relatively low in the mobility of immigrants so that in general, the Covid-19 cases in South Bengkulu can still be monitored with the majority of cases of the infection being people who just travelled or came back from out of town (Usmin, 2020).

According to Anderson (1979) policy is an action taken by the government to overcome a problem. Then a policy program must be 
implemented in order to have the desired impact (Roring et al., 2021). In the face of the Covid-19 pandemic, the South Bengkulu Regency Government, on March 16, 2020, took the policy of closing schools throughout South Bengkulu. Specifically, Kindergarten to Middle School for 2 weeks. The South Bengkulu Regency Government has also temporarily suspended finger print attendance for State Civil Apparatus and provided disinfectant in offices (Mediacenter, 2020).

Then on March 22, 2020, the South Bengkulu district government also built a checkpoint to prevent Corona Virus or Covid-19 at three border points, namely the Air Tenam post, Ulu Manna Subdistrict, Selali, Pino Raya and Sukajaya, Kedurang Ilir. We are socializing prevention measures for the transmission of the Covid-19 virus, preparing isolation rooms, and making masks in collaboration with local artisans to anticipate and prevent Covid 19 to South Bengkulu. The South Bengkulu Regency Government is also refocusing an Rp. 6 billion budget to avoid the Coronavirus (Covid-19) outbreak. Asking the village and subdistrict governments to re-comb or reschedule the use of village and subdistrict funds to help local government efforts to prevent Covid 19 from entering the South Bengkulu area (Oktriandi, 2020).

All these preventive efforts, of course, have an impact on social life in the community. Many people stay at home, so economic activity is running slower than usual. Data from the Central Bengkulu Regency Statistics Agency recorded that Bengkulu province experienced a slowdown in economic growth by $0.02 \%$ in 2020 , and specifically, South Bengkulu district experienced a slowdown by $0.26 \%$. This figure is the highest figure of the economic growth rate of other communities in Bengkulu, but this figure is far from the economic growth in 2019, which reached $4.47 \%$. The most significant contributors to regional income in South Bengkulu are consecutively, namely agriculture, forestry and fisheries, trade, government administration and social security, transportation, finance and services. (Badan Pusat Statistik Kabupaten Bengkulu Selatan, 2021).

Apart from affecting the economy, the Covid-19 pandemic is pressing local governments to handle better health. The existing social reality is that most health facilities in the regions or districts are not as good as those in urban areas. This creates more significant concern, especially as we know that in the early days of the pandemic, all people had to adjust and explore ways to deal with the infection of the Covid19 virus. South Bengkulu is a district that does not have a CPR laboratory facility to detect Covid-19 disease. So that patients suspected or have symptoms close to Covid-19 have to wait sometime to get the test results because Bengkulu province samples of patients suspected of being Covid19 must be taken to the PCR test laboratory in South Sumatra (Usmin, 2020).

\section{South Bengkulu Regency Government Policy in the New Normal era}

Entering the middle of 2020, there was a policy transformation from before, namely right in June the Indonesian government took a policy to start the habits of the new normal era. The new normal is an acceleration step in handling Covid-19 in the health, social and economic fields. The purpose of implementing the new normal concept is to get used to the new lifestyle of the community while 
still paying attention to Health protocols in order to suppress Covid19 cases. Edward sees policy implementation as a dynamic process, there are factors that influence the implementation of a policy (Roring et al., 2021). In this case, the government is taking policy steps so that people can implement new habits such as being required to wash their hands, wear masks in public places, and maintain social distance when socializing.

The New Normal policy is carried out to restore the economy so that it can return to normal, the Coordinating Ministry for Economic Affairs has compiled the stages or phases of opening business and industrial activities after the spread of the Covid-19 pandemic. Consisting of 5 phases, the first on June 1 , Industry and services can operate with the Covid-19 health protocol, malls are not allowed to operate, except for shops selling masks \& health facilities. The second phase is on June 8. Stores, markets and malls are allowed to open shops but with health protocols. In the third phase, on June 15, the school was opened but with a shift system. The fourth phase, July 6, opens economic activities with additional evaluations for the gradual opening of restaurants, cafes, bars, and others with strict hygiene protocols. Religious activities are allowed with a limited number of worshipers. The fifth phase, 20-27 July, valuation for four steps and the opening of places or large-scale economic and social activities. End of July or early August 2020 , it is hoped that all financial activities will be opened (Idris, 2020).

The policies issued by the Central Government must be fully adapted to a region because not all conditions of Covid-19 transmission in Indonesian territory are the same. South Bengkulu Regency adopted policies from the central Government by refocusing and reallocating the budget from both the APBN and APBD for handling Covid-19. Refocusing and reallocation are prioritized in the health sector, managing social networks and assisting the business world (Kominfo Provinsi Bengkulu, 2020).

The implementation of refocusing of these funds was realized in the regions with the South Bengkulu Regent Regulation Number 25 of 2020 signed on July 9, 2020, concerning Guidelines for Implementation of Village Cash Direct Aid for Handling the Impact of Corona Virus Disease 2019 (Covid-19) in South Bengkulu Regency in 2020. the seriousness of local government policies. This regent regulation contains mechanisms around individuals or parties entitled to receive aid funds to the tool for collecting aid funds. Village Cash Direct Aid, called BLT Desa, is a social safety net program or social assistance from the Government in the form of money for the poor from the Village Fund for handling the impact of Corona Virus Disease 2019 (Covid-19) (JDIH BPK RI, 2020).

In entering the new average era, according to the focus of the central Government is the implementation of strict health protocols, the South Bengkulu regional government also issued Regent Regulation Number 32 of 2020, which was signed on September 14, 2020, concerning the Application of Discipline and Law Enforcement of Health Protocols as Efforts to Prevent and Control Corona Virus Disease 2019 (Covid-19). Every individual, business actor, manager, organizer and person in charge of public facilities must apply the $4 \mathrm{M}$, namely wearing a mask, washing hands, maintaining distance and avoiding crowds. This district head 
regulation regulates the parties responsible for conducting field control and the sanctions imposed for violators of these rules (JDIH BPK RI, 2020).

In the new average era, the South Bengkulu district government has also closed two covid-19 posts in Selali Village, Pino Raya District and Sukamaju District, Kedurang Ilir District, the Task Force Team for the Acceleration of Handling Covid-19 in South Bengkulu Regency will also immediately close the South Bengkulu border post with the Province. South Sumatra in Air Tenam Village, Ulu Manna District. This policy was taken after seeing that there were no confirmed positive cases of Covid-19 in the South Bengkulu Regency since the end of May 2020 (Bengkulu Today, 2020). Apart from that, for social activities, currently, a wedding in South Bengkulu has been held. This guidebook was published after the South Bengkulu Regency Government in July 2020 allowed residents to hold wedding receptions both in buildings and open fields by implementing established health protocols. For every wedding ceremony in South Bengkulu, the maximum number of guests is not more than 500 people. This is done to prevent the accumulation of people or crowds that can cause Coronavirus transmission (Usmin, 2020).

At the end of 2020, face-toface schools have also been implemented at the high school and junior high school level in South Bengkulu, even though they only have a capacity of $50 \%$ of students in the class but this is expected to be something positive, especially for students who do not have the financial ability to get learning facilities adequate online (Usmin, 2020). In the health sector, on January 31, 2021, the Covid-19 vaccine was distributed to health centers in South Bengkulu district (Dinas Kesehatan Kabupaten Bengkulu Selatan, 2021). And the vaccination itself has started to be injected on February 2, 2021, as the first recipient of this regional vaccine is the provincial secretary of South Bengkulu, Yudi Satria (Mediacenter, 2021).

\section{Initial Policy of Pidie Regency Government Before New Normal}

Countries are responding in various ways because of the increasing cases of Covid-19. Several governments responded immediately by restricting population mobility and halting most economic activities (McKenzie \& Adams, 2020). The spread of covid-19 is a problem that must be handled by the Government, primarily regional governments, which must be alert because regions are the base for the spread of the virus. Pidie with a population of 443,718 people, which is the second largest number in Aceh Province. According to data from the Pidie Health Office, one positive case appeared for the first time in April 2020 , and the addition of two points in July and until September continued to increase sharply to 46 patients based on the results of the PCR test issued by the Aceh Balitbangkes. The alacrity of the Government is an effort to prevent the spread of the Coronavirus in the interests and needs of the community for a healthier life.

The first step of the Pidie Government's policy in dealing with Covid-19 was by building a Pidie Covid-19 Post within the Pidie Health Service complex. This post has been operating since March 17, 2020; by providing four ambulances and isolation rooms for handling Covid-19 (Saimima, 2020), Then the Pidie Government also appealed to reduce 
outdoor activities, especially in crowded and public places such as carrying out office activities at home (WFH) and temporarily closing schools and replacing them through online media (Rakyat Aceh, 2020). The imposition of curfew restrictions is also carried out to reduce outdoor activities following Central Government regulations regarding Large-Scale Social Restrictions in the Context of Accelerating Handling of Covid-19 (Pemprov Aceh, 2020).

Almost all aspects of life are constrained by the pandemic, including the economy of the Pidie Regency, which has also experienced a decline. In the fourth quarter of 2020, Aceh's economy experienced a decrease compared to the previous quarter. Aceh's economy in the fourth quarter of 2020 experienced a contraction of $-2.99 \%$ (YoY), down from the last quarter, which only contracted $-0.11 \%$ (YoY). When viewed from the demand side, the decline that occurred was mainly due to weakening household and government spending. The slowdown in household consumption was caused by the Covid-19 pandemic, which required both private and Government parties to implement WFH policies, limiting working hours to layoffs, which affected people's income to decrease. According to data from the Ministry of Manpower and BPJS Tenaga Kerja, it shows that 7,499 informal businesses have been affected and have lost their businesses, and 4,267 workers have been sent home (LPP Aceh, 2021).

The effect of Covid-19 has had a tremendous impact on the community below, so the Government must have a strategy to overcome it by making policy strategies to ease the burden on society. The Pidie government received assistance from the Aceh Government in essential food assistance, which was distributed to 8,069 heads of families (KK) in 23 sub-districts in Pidie. (Ismail, 2020). The Pidie government also utilized funds belonging to the Gampong (village) originating from the APBN, which were used for Government needs, shifted and converted to handling covid 19 in the form of Direct Cash Assistance (BLT) (Muttaqien, 2021).

Health management due to the pandemic in Pidie is also still constrained due to inadequate health facilities. Like in South Bengkulu, the availability of health facilities in Pidie is still not as good as those in urban areas. Countermeasures due to viruses continue to adapt to the conditions of the affected areas. The Pidie government is obliged to provide PPE such as PPE for medical personnel, although still those who take the initiative to use raincoats in treating patients. Through the assistance of the Aceh Health Office, the Pidie Government has received aid in the form of 30 sets of PPE, four boxes of Rapid test, 60 N95 masks and 3,000 TB masks. (Pasee, 2020). The Pidie government continues to strive and strive to deal with Covid19 for the needs of a healthier society. Then, the involvement of various parties has also immensely helped government programs in tackling Covid-19.

\section{Pidie Regency Government Policy in the New Normal era}

Pidie District was once declared a red zone at the beginning of the spread of the Coronavirus in Aceh. Based on circular number 440/7810 concerning 'Implementation of a Productive and Safe Society for Corona Virus Disease 2019 (Covid-19) on the Red Zone and Green Zone Criteria', which the Governor of Aceh signed on June 2, 2020, addressed to regents/mayors in Aceh, stated that there are nine 
areas that are at high risk of the spread of the Coronavirus, including Pidie Regency (Setyadi, 2020). However, the Covid-19 cases in Pidie are decreasing. According to data on the Covid-19 subject in Pidie until April 2021, 489 confirmed cases, 396 recovered, and 52 people died.

In the new normal, the Aceh government instructed the local government to prepare for the implementation of the new normal. The government will provide socialization of the preparation of facilities and infrastructure for prevention and handling so that productive people remain safe from Covid-19. Seeing the development of the Covid 19 case in Pidie, which has now entered the green zone area based on the provincial government policy, it will impose a new normal. Then, the Deputy Regent of Pidie Regency will re-evaluate the Covid 19 policy by setting the application of the new normal. The school, which was conducted online for six months at the start of the pandemic, has implemented a teaching and learning process in the school environment on July 13, 2020, then according to the Health protocol, namely maintaining distance by reducing the number of students in the class and students are encouraged to sit alone at one table (Pidiekab.go.id, 2020). Not only schools, office activities, Islamic boarding schools and markets were also loosened. With the establishment of a new normal in the Pidie Regency, it can strengthen the economy and health.

The mass vaccination program that the Government has launched has fostered optimism for the national and regional economic recovery. However, due to the limited number of vaccines, the Government has made the vaccination a priority scale. To reduce the number of Covid19 transmissions, the Pidie Health
Office continues to strengthen across sectors to implement the Covid-19 vaccine. According to the Aceh Economic Growth Report, economic growth in 2021 is estimated to grow higher than in 2020, and this is driven by optimism for economic activity after mass vaccination (LPP Aceh, 2021).

\section{Conclusion}

The global pandemic that has occurred so far has clearly created a society. Therefore, the Government must provide protection to the public in preventing and handling Covid-19 cases in accordance with the mandate of the 1945 Constitution of the Republic of Indonesia. Both countries and regions continue to try to implement and transform policies in accordance with this pandemic situation. In this case, the steps issued by the government, both South Bengkulu Regency and Pidie Regency to handle the Covid-19 case, are directives from the Central Government's policy which are then adjusted to the conditions in each district, both South Bengkulu Regency and Pidie Regency.

The implementation of policies from the two districts is not much different, although at the beginning of the case, Pidie District was once designated a red zone and so far there has been a decline in positive cases of Covid 19 and was again declared a green zone. The initial steps taken by the South Bengkulu government and the Pidie government were to reduce outdoor activities, especially in crowded places, WFH, and establish a Covid-19 prevention checkpoint.

The economic and health impacts caused by Covid-19 significantly affect people's lives. Restrictions on economic activities at a macro level reduce economic growth and cause many people to lose their jobs. The Government has 
designed various new policies to reduce the spread and handling of this virus. The economic downturn in these two regions was mainly due to the savings in household expenditures used to refocus the Covid-19 handling budget.

\section{Acknowledgements}

We would like to express our gratitude to Universitas Muhammadiyah Yogyakarta, Indonesia.

\section{References}

Agustino, L. (2020). Analisis Kebijakan Penanganan Wabah Covid-19: Pengalaman Indonesia. Jurnal Borneo Administrator, 16(2), 253-270.

Badan Pusat Statistik Kabupaten Bengkulu Selatan. (2018, Juli 07). Luas Daerah, Jumlah Penduduk dan Kepadatan Penduduk Menurut Kecamatan 2016. Retrieved from Badan Pusat Statistik Kabupaten Bengkulu Selatan:

https://bengkuluselatankab.bps. go.id/statictable/2017/10/26/1

18/luas-daerah-jumlahpenduduk-dan-kepadatanpenduduk-menurut-kecamatan2016-.html

Badan Pusat Statistik Kabupaten Bengkulu Selatan. (2021, April 1). Produk Domestik Regional Bruto Kabupaten Bengkulu Selatan menurut Lapangan Usaha tahu 2016-2020. Retrieved from Badan Pusat Statistik Kabupaten Bengkulu Selatan.

Bengkulu Today. (2020, Juni 16). New Normal, Pemkab Bengkulu Selatan Tutup Posko Air Tenam dan Susun Panduan Pesta Pernikahan. Retrieved from Bengkulutoday: https://www.bengkulutoday.co $\mathrm{m} /$ new-normal-pemkabbengkulu-selatan-tutup-poskoair-tenam-dan-susun-panduan- pesta-pernikahan

Covid19 Kabupaten Bengkulu Selatan. (2021, April 01). Info Kasus COVID-19 di Kab. Bengkulu Selatan. Retrieved from Covid19 Kabupaten Bengkulu Selatan: https://covid19.bengkuluselatan kab.go.id/infokasusbengkuluselatan/

Dinas Kesehatan Kabupaten Bengkulu Selatan. (2021, Januari 31). PENDISTRIBUSIAN VAKSIN COVID 19 KE PUSKESMAS SE KABUPATEN BENGKULU SELATAN. Retrieved from dinkes.bengkuluselatankab.go.id: https://dinkes.bengkuluselatank ab.go.id/pendistribusian-vaksincovid-19-ke-puskesmas-sekabupaten-bengkulu-selatan/

Edward, G. C. (1980). Implementing Public Policy. Washington DC: Congressional Quarterly Press.

Idris, M. (2020, Mei 26). Mulai 1 Juni, Ini Skenario Tahapan New Normal untuk Pemulihan Ekonomi. Retrieved from Kompas.com:

https://money.kompas.com/rea d/2020/05/26/073708726/mul ai-1-juni-ini-skenario-tahapannew-normal-untuk-pemulihanekonomi?page $=$ all

JDIH BPK RI. (2020 , Juli 09). Petunjuk Pelaksanaan Bantuan Langsung Tunai Desa untuk Penanganan Dampak Corona Virus Disease 2019 (Covid-19) di Kabupaten Bengkulu Selatan . Retrieved from JDIH BPK RI Database Peraturan:

https://webcache.googleusercon tent.com/search?q=cache:uxjEw xJ2RIYJ:https://peraturan.bpk.go .id/Home/Details/148819/perb up-kab-bengkulu-selatan-no-25tahun$2020+\& \mathrm{~cd}=1 \& \mathrm{hl}=\mathrm{id} \& \mathrm{ct}=\mathrm{clnk} \& \mathrm{gl}$ =id\&client=firefox-b-d

JDIH BPK RI. (2020, September 14). Penerapan Disiplin dan 
Penegakan Hukum Protokol Kesehatan sebagai Upaya Pencegahan dan Pengendalian Corona Virus Disease 2019 (Covid-19) . Retrieved from JDIH BPK RI Database Peraturan: https://webcache.googleusercon tent.com/search?q=cache:d_TfLfl 40wkJ:https://peraturan.bpk.go. id/Home/Details/148838/perbu p-kab-bengkulu-selatan-no-32tahun$2020+\& \mathrm{~cd}=1 \& \mathrm{hl}=\mathrm{id} \& \mathrm{ct}=\mathrm{clnk} \& \mathrm{gl}$ $=i d \&$ client=firefox-b-d

Kominfo Provinsi Bengkulu. (2020, September 05). Dampak Kebijakan Pemerintah di Masa Pandemi Mulai Tampak, Geliat Ekonomi Perlahan Tumbuh. Retrieved from Pemerintah Provinsi Bengkulu: https://bengkuluprov.go.id/dam pak-kebijakan-pemerintah-dimasa-pandemi-mulai-tampakgeliat-ekonomi-perlahantumbuh/

LPP Aceh. (2020). Kalender Publikasi Laporan Perekonomian Provinsi ( $L P P$ ) Aceh. Retrieved from LPP Aceh:

https://pidiekab.bps.go.id/press release/2021/02/05/122/pertu mbuhan-ekonomi-acehtriwulan-iv-2020.html

Luth, L., \& Meriwijaya, M. (2021). Implementasi

Kebijakan Pencegahan Dan Penanganan Covid-19 Di Pondok Pesantren Modern Selamat Kabupaten Kendal, Jawa Tengah. Kybernan: Jurnal Studi Kepemerintahan, 4(1), 90-109. https://doi.org/10.35326/kyber nan.v4i1.1142

McKenzie, G., \& Adams, B. (2020). A country comparison of placebased activity response to COVID-19 policies. Applied Geography, 125. https://doi.org/10.1016/j.apgeo g.2020.102363

Mediacenter. (2020, April 16). Antisipasi Corona, Pemkab Bengkulu Selatan Liburkan Sekolah. Retrieved from Media Center Kabupaten Bengkulu Selatan:

https://mediacenter.bengkulusel atankab.go.id/2020/03/16/antis ipasi-corona-pemkab-bengkuluselatan-liburkan-sekolah/

Mediacenter. (2021, Februari 02). Sekda Terima Vaksin Covid 19 Pertama di Kabupaten Bengkulu Selatan. Retrieved from Media Center Kabupaten Bengkulu Selatan:

https://mediacenter.bengkulusel atankab.go.id/2021/02/01/sekd a-terima-vaksin-covid-19pertama-di-kabupatenbengkulu-selatan/

Mintrom, M., \& O'Connor, R. (2020). The importance of policy narrative: effective government responses to Covid-19. Policy Design and Practice, 3(3), 205227.

https://doi.org/10.1080/25741 292.2020.1813358

Muttaqien, A. (2021). Tinjauan Yuridis Penggunaan dan Pengawasan Dana Gampong untuk Batuan Langsung Tunai Dampak Covid 19 di Kabupaten Pidie. Jabal Ghafur Conference on Research \& Comunity Service, 1(1).

http://journal.unigha.ac.id/inde x.php/SemNas

Oktriandi, E. (2020, Maret 30). Pemkab Bengkulu Selatan Refocusing Anggaran Rp 6 Miliar untuk Covid-19. Retrieved from Bengkulunews.co.id:

https://www.bengkulunews.co.i d/pemkab-bengkulu-selatanrefocusing-anggaran-rp-6-miliaruntuk-covid-19

Pasee, M. (2020, April). Ini Langkah Pemerintah dan Anggaran untuk 
Pencegahan Covid-19 di Pidie. The Aceh Trend. https://www.acehtrend.com/20 20/04/05/ini-langkahpemerintah-dan-anggaranuntuk-pencegahan-covid-19-dipidie/

Pemprov Aceh. (2020). Pemerintah Aceh Evaluasi Kebijakan Terkait Penanganan Covid-19. https://humas.acehprov.go.id/p emerintah-aceh-evaluasikebijakan-terkait-penanganancovid-19/

Pidiekab.go.id. (2020). Wakil Bupati: Pidie Sudah Masuk Zona Hijau, Proses Belajar-Mengajar Akan Segera Dilaksanakan. http://pidiekab.go.id/2020/07/ wakil-bupati-pidie-sudahmasuk-zona-hijau-prosesbelajar-mengajar-akan-segeradilaksanakan/

Purnamasari, D. M. (2021, April 16). UPDATE 16 April: Ada 107.297 Kasus Aktif Covid-19 di Indonesia. Retrieved from Kompas.com: https://nasional.kompas.com/re ad/2021/04/16/16502631/upd ate-16-april-ada-107297-kasusaktif-covid-19-di-indonesia

Rakyat Aceh. (2020). Bupati Pidie Perintahkan Sekolah ditutup 14 Hari. Harianrakyataceh.Com. https://harianrakyataceh.com/2 020/03/18/bupati-pidieperintahkan-sekolah-ditutup-14hari/

Roring, A. D., Mantiri, M. S., \& Lapian, M. T. (2021). Implementasi Kebijakan Pemerintahann Dalam Penanganan Virus Corona (Covid 19) di Desa Ongkaw 1 Kecamatan Sinonsyang
Kabupaten Minahasa Selatan. Jurnal Ilmu Pemerintahan, 1(2), 1-11.

Saimima, C. (2020, April). Apa yang telah dilakukan Gugus Tugas Covid-19 dalam Dua Bulan Ini? Sinarpidie.Co. https://sinarpidie.co/news/apayang-telah-dilakukan-gugustugas-covid-19-pidie-dalam-duabulan/index.html

Setyadi, A. (2020). Pidie Jadi Zona Merah Corona, Pemkab Minta Warga Tak Panik. Detiknews. https://news.detik.com/berita/d -5042173/pidie-jadi-zonamerah-corona-pemkab-mintawarga-tak-panik?single $=1$

Syaukani, H. (2004). Efektifitaas Implementasi Kebijakan Otonomi Daerah. Jakarta: Citra Utama.

Usmin. (2020, April 11). 1 PDP Covid19 Meninggal Dunia di RSU Bengkulu Selatan. Retrieved from Beritasatu.com: https://www.beritasatu.com/na sional/619289/1-pdp-covid19meninggal-dunia-di-rsubengkulu-selatan

Usmin. (2020, Juli 05). Bengkulu Selatan Terbitkan Panduan Pesta Pernikahan Di Tengah Pandemi Covid-19. Retrieved from Berita Satu:

https://www.beritasatu.com/na sional/652317/bengkuluselatan-terbitkan-panduanpesta-pernikahan-di-tengahpandemi-covid19

Vining, D. L. (2017). Policy Analysis: Concepts and Practice 6th Edition. New York: Routledge.

(C) 2021 by the Authors. Submitted for possible open access publication under the terms and conditions of the Creative Commons Attribution- ShareAlike (CC BY SA) license (https://creativecommons.org/licenses/by-sa/4.0/). 